\title{
Turkish League Against Rheumatism National Recommendations for the Management of Ankylosing Spondylitis
}

\author{
Türkiye Romatizma Araştırma ve Savaş Derneği Ankilozan Spondilit \\ Ulusal Tedavi Önerileri
}

\author{
Hatice BODUR, ${ }^{1}$ Filiz SİVAS, ${ }^{1}$ Özlem YILMAZ, ${ }^{1}$ Salih ÖZGÖÇMEN,${ }^{2}$ Rezzan GÜNAYDIN, ${ }^{3}$ Taciser KAYA, ${ }^{3}$ Şebnem ATAMAN, ${ }^{4}$

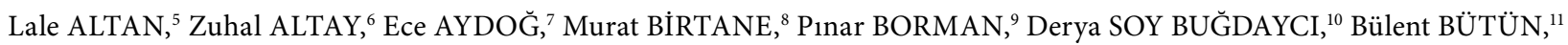 \\ Haşim ÇAKIRBAY, ${ }^{12}$ Tuncay DURUÖZ, ${ }^{13}$ Gülcan GÜRER, ${ }^{14}$ Simin HEPGÜLER, ${ }^{15}$ Ayhan KAMANLI, ${ }^{16}$ Ömer KURU, ${ }^{17}$ \\ Ayşe KÜÇÜKDEVECİ, ${ }^{18}$ Barış NACIR, ${ }^{9}$ Neşe ÖLMEZ, ${ }^{19}$ Aylin REZVANİ, ${ }^{20}$ Burcu ÇÖREKÇİ YANIK ${ }^{12}$
}

\begin{abstract}
${ }^{1}$ Department of Physical Medicine and Rehabilitation, Ankara Numune Education and Research Hospital, Ankara, Turkey; ${ }^{2}$ Department of Physical Medicine and Rehabilitation, Medical Faculty of Erciyes University, Rheumatology Division, Kayseri, Turkey; ${ }^{3}$ Department of Physical Medicine and Rehabilitation, Izmir Bozyaka Education and Research Hospital, Izmir, Turkey; ${ }^{4}$ Department of Physical Medicine and Rehabilitation, Medical Faculty of Ankara University, Rheumatology Division, Ankara, Turkey; ${ }^{5}$ Department of Physical Medicine and Rehabilitation, Medical Faculty of Uludă̆ University, Bursa, Turkey; ${ }^{6}$ Department of Physical Medicine and Rehabilitation, Medical Faculty of İnönü University, Malatya, Turkey; ${ }^{7}$ Department of Physical Medicine and Rehabilitation, Medical Faculty of Yeditepe University, İstanbul, Turkey; ${ }^{8}$ Department of Physical Medicine and Rehabilitation, Medical Faculty of Trakya University, Edirne, Turkey; ${ }^{9}$ Department of Physical Medicine and Rehabilitation, Ankara Education and Research Hospital, Ankara, Turkey; ${ }^{10} I_{\text {stanbul Physical Medicine and }}$

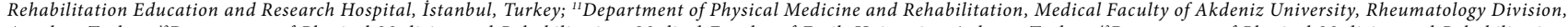
Antalya, Turkey; ${ }^{12}$ Department of Physical Medicine and Rehabilitation, Medical Faculty of Fatih University, Ankara, Turkey; ${ }^{13}$ Department of Physical Medicine and Rehabilitation, Medical Faculty of Celal Bayar University, Rheumatology Division, Manisa, Turkey; ${ }^{14}$ Department of Physical Medicine and Rehabilitation, Van State Hospital, Rheumatology Division, Van, Turkey; ${ }^{15}$ Department of Physical Medicine and Rehabilitation, Medical Faculty of Ege University, İzmir, Turkey; ${ }^{16}$ Department of Physical Medicine and Rehabilitation, Medical Faculty of Firat University, Rheumatology Division, Elazı̆g, Turkey; ${ }^{17}$ Department of Physical Medicine and Rehabilitation, Medical Faculty of Ondokuz Mayis University, Samsun, Turkey; ${ }^{18}$ Department of Physical Medicine and Rehabilitation, Medical Faculty of Ankara University, Ankara, Turkey; ${ }^{19}$ Department of Physical Medicine and Rehabilitation, İzmir Atatürk Education and Research Hospital, İzmir, Turkey; ${ }^{20}$ Department of Physical Medicine and Rehabilitation, Medical Faculty of Bezmialem Vakif University, İstanbul, Turkey
\end{abstract}

Objectives: To develop Turkish League Against Rheumatism (TLAR) National Recommendations for the management of ankylosing spondylitis (AS).

Materials and methods: A scientific committee of 25 experts consisting of six rheumatologists and 19 physical medicine and rehabilitation specialists was formed by TLAR. Recommendations were based on the 2006 ASsessment in Ankylosing Spondylitis International Working Group (ASAS)/European League Against Rheumatism (EULAR) recommendations and a systematic review of associated publications between January 2005 and September 2010. A Delphi process was used to develop the recommendations. Twelve major recommendations were constructed for the management of AS. Voting using a numerical rating scale assessed the strength of each recommendation.

Results: The 12 recommendations include patient assessment, patient follow-up along with pharmacological and nonpharmacological methods. Some minor additions and changes have been made to the ASAS/EULAR recommendations. All of the recommendations had sufficient strength.

Conclusion: National recommendations for the management of AS were developed based on scientific evidence and consensus expert opinion. These recommendations will be updated regularly in accordance with recent developments.

Key words: Ankylosing spondylitis; national recommendations; treatment.
Amaç: Türkiye Romatizma Araştırma ve Savaş Derneği'nin (TRASD) Ankilozan Spondilit (AS) için ulusal tedavi önerilerinin oluşturulmasıdır.

Gereç ve yöntemler: TRASD tarafından altı Romatoloji ve 19 Fiziksel Tıp ve Rehabilitasyon uzmanı olmak üzere toplam 25 kişiden oluşan bir bilimsel kurul oluşturuldu. Önerilerde 2006 yılında yayınlanan Ankilozan Spondilit Değerlendirme Uluslararası Çalışma Grubu (ASAS)/Romatizmaya karşı Avrupa Ligi (EULAR) önerileri ve Ocak 2005 - Eylül 2010 arasında yayınlanmış olan ilişkili yayınlar konusundaki sistematik bir inceleme temel alındı. Öneriler oluşturulurken Delphi süreci kullanıldı. Ankilozan spondilit tedavisi ile ilgili 12 ana öneri oluşturuldu. Oylama yapılarak önerilerin güçlülük düzeyi bir nümerik derecelendirme skalası ile belirlendi.

Bulgular: On iki öneri hasta değerlendirilmesini, hasta takibini ve farmakolojik ve non-farmakolojik yöntemleri içermektedir. ASAS/EULAR önerilerine bazı ilaveler ve önerilerde bazı küçük değişiklikler yapılmıştır. Tüm öneriler yeterli kuvvete sahipti.

Sonuç: Bilimsel kanıtlar ve uzmanların görüş birliği ile AS tedavisine yönelik ulusal öneriler oluşturulmuştur. Bu öneriler, yeni gelişmeler doğrultusunda düzenli olarak güncellenmelidir.

Anahtar sözcükler: Ankilozan spondilit; ulusal öneriler; tedavi.

Correspondence: Filiz Sivas, M.D. Ankara Numune Eğitim ve Araştırma Hastanesi Fizik Tedavi ve Rehabilitasyon Kliniği, 06100 Altındağ, Ankara, Turkey. Tel: +90 312 - 5084803 e-mail: filiz_sivas@yahoo.com

(c)2011 Turkish League Against Rheumatism. All rights reserved. 
Ankylosing spondylitis (AS) is a chronic, inflammatory rheumatic disease with an unknown etiology. In Turkey, the prevalence of AS has been reported to be $0.49 \%{ }^{\left[{ }^{[1]}\right.}$ The disease primarily affects young individuals and male adults and leads to significant loss of function and deterioration in quality of life. ${ }^{[2,3]}$

In the past, non-steroidal anti-inflammatory drugs (NSAIDs), providing symptom control, and physical therapy were the mainstays of treatment for AS. However, significant advances have been accomplished in AS management in the last decade after the introduction of biological drugs. Physicians need to be updated on current and evidence-based information regarding the benefits, risks, and socioeconomic costs of these therapies. Evidence-based medicine has increasingly become important in treatment decisions. The most practical way of notifying physicians about evidence-based medical information is to develop guidelines regarding diagnosis and treatment as well as recommendations for management.

As a combined effort, the ASsessment in Ankylosing Spondylitis International Working Group (ASAS) and European League Against Rheumatism (EULAR) developed 10 key recommendations for the management of AS based on current evidence and consensus expert opinion and published these recommendations in 2006. A patient version of these recommendations was also published in 2009. ${ }^{[4-6]}$ Recommendations for the management of AS were recently updated in 2010. ${ }^{[7]}$

This study is the development project of the Turkish League Against Rheumatism (TLAR) and presents national recommendations for the management of AS. Our aim was to develop recommendations for the management of AS in light of the ASAS/EULAR recommendations, current evidence, and national conditions.

\section{MATERIALS AND METHODS}

The methodology of the study was based on the EULAR standardized operating procedures. ${ }^{[8]}$ A scientific committee comprised of experts was formed by TLAR in order to develop recommendations for the management of AS. This committee included 25 experts consisting of six rheumatologists and 19 physical medicine and rehabilitation specialists. The first meeting was held in Ankara on July 2 $2^{\text {nd }}, 2010$. A consensus regarding methods and process was achieved.

Physicians specializing in the diagnosis and management of AS were the target physician group for these recommendations. A systematic literature search was performed by two specialists (HB, FS) who did not participate in the recommendation voting process. These new recommendations were based on the ASAS/EULAR recommendations published in 2006. ${ }^{[5]}$ The ASAS/EULAR recommendations included a literature search for the period between January 1996 and December 2004. Therefore, a systematic literature search was performed from January 2005 to September 2010 via the Medline (http//www.pubmed.gov), the Cochrane Library, and the Turkish Medical Index databases, and these served as the main research sources for the new recommendations. Scientific studies were categorized according to the traditional hierarchy of evidence (table 1). Assessment of validation was performed for reviews, and only those which involved all of the criteria were used. ${ }^{[8,9]}$ Current articles along with the information retrieved by the literature search were sent as a brief report to the scientific committee. Members of the scientific committee were asked to provide independent recommendations. Recommendations for management were then assessed using the Delphi technique. The acceptance level for recommendations was set at $70 \%$. Recommendations for management were proposed after two Delphi rounds of voting. Following these processes for the development of recommendations conducted through electronic mail, a second meeting was held in Ankara on April $29^{\text {th }}, 2011$ to determine the strength of the recommendations, which was assessed by voting using a numerical rating scale. The recommendations for management of AS are presented in table 2.

\section{National Recommendations for the Management of Ankylosing Spondylitis}

1. Treatment should be planned according to the characteristics of the patient taking the following points into consideration:

- Current symptoms and findings of the disease (axial, peripheral, entheseal, extra-articular involvement),

\begin{tabular}{l} 
Table \\
\hline Category of evidence \\
\hline Ia $\quad$ Meta-analysis of randomized controlled trials \\
Ib $\quad$ Randomized controlled trials \\
IIa $\quad$ Controlled study without randomization \\
IIb $\quad$ Semi-experimental studies \\
III $\quad$ Non-experimental descriptive studies, such as \\
IV $\quad$ comparative, correlation, and case-control studies
\end{tabular}


Table 2. Turkish League Against Rheumatism National Recommendations for the management of ankylosing spondylitis

1 Treatment should be planned according to the characteristics of the patient taking the following points into consideration:

- Current symptoms and findings of the disease (axial, peripheral, entheseal, extra-articular involvement)

- Stage of symptoms, clinical findings, and prognostic indicators (disease activity/inflammation, pain, functionality, activity and participation restrictions, structural damage, hip involvement, spinal deformities)

- Demographic and medical characteristics (age, gender, comorbidities, other drugs)

- Aspirations and expectations of the patient.

2 Extra-articular involvements should be monitored and treated in collaboration with related specialties.

3 By considering the clinical presentation and ASAS core set, the follow-up of patients should include patient history, clinical parameters, laboratory tests, and imaging findings. The frequency of follow-up should be decided according to the severity of disease and symptoms along with drug treatment.

4 Pharmacological and non-pharmacological treatments should be used in combination for optimal management of AS.

5 Non-pharmacological treatment methods principally include patient education and a regular exercise program (floor and water exercises). In addition, balneotherapy and spa therapy along with physical treatment modalities and occupational therapy are also included.

- Patient associations and help groups may be useful.

6 NSAIDs are the first line treatment to alleviate pain and stiffness.

- In patients with higher risk for gastrointestinal side effects, combination of an NSAID and a gastroprotective agent or a selective COX-II inhibitor can be used.

7 For pain control, analgesics such as paracetamol and opioids may be considered when NSAIDs are inadequate, contraindicated, and/or poorly tolerated.

8 Corticosteroid injections can be administered to local sites of inflammation. There is not enough evidence supporting the use of systemic steroids for axial disease.

9 There is no evidence regarding the effect of disease-modifying agents (including sulfasalazine: SSZ, methotrexate: MTX) on axial disease, but SSZ may be used in peripheral arthritis.

10 Anti-TNF treatment should be given when the activity of the disease continues despite conventional treatments according to the ASAS recommendations. There is no evidence that approves of the usage of DMARDs before, or together with, anti-TNF treatment in patients with axial disease.

11 Total hip arthroplasty should be applied to patients with refractory pain or disability and radiographic structural damage which is unrelated to age. Spinal surgical methods, such as corrective osteotomy and stabilization procedures, may be helpful in selected patients.

12 Spinal pain of sudden onset which cannot be directly attributed to inflammation should be investigated. The assessment and opinion of a spinal surgeon should be sought in the presence of an acute vertebral fracture.

ASAS: The ASsessment of SpondyloArthritis International Society; AS: Ankylosing spondylitis; COX: Cyclooxygenase; DMARDs: Disease-modifying anti-rheumatic drugs; NSAIDs: Non-steroidal anti-inflammatory drugs; TNF: Tumor necrosis factor.

- Stage of symptoms, clinical findings, and prognostic indicators (disease activity/ inflammation, pain, functionality, activity and participation restrictions, structural damage, hip involvement, spinal deformities),

- Demographic and medical features (age, gender, comorbidities, other drugs),

- Aspirations and expectations of the patient.

This initial recommendation will provide help in making treatment decisions and may serve as a guide. Ankylosing spondylitis causes significant functional loss along with activity and participation restrictions. It is especially important to predict patients with a poor prognosis. Poor prognostic indicators reported by the $3 \mathrm{E}$ (Evidence, Experts and Exchange) Initiative include the presence of radiographic structural damage at baseline evaluation, hip involvement, disease onset at a young age, persistently high levels of acute phase reactants, and disease activity [level of evidence IV].[10]

The disease runs a course with flare-ups (increases in disease activity) occurring in most patients with AS. Stone et al. ${ }^{[1]}$ reported that $96 \%$ of patients had flare-ups and that approximately $80 \%$ of patients had constant symptoms with single/repeated flare-ups resulting in a poorer health status for these patients [level of evidence III]. This result provided a new insight into the treatment approach and introduced the need for continuous treatment in most of the patients. ${ }^{[1]}$ 
Until recently, there was not enough evidence to determine treatment response according to patient characteristics. Assessment of the treatment response according to patient characteristics has become more important after the introduction of anti-tumor necrosis factor (TNF) agents which are effective but expensive alternatives to previous standards for treatment, and several studies have been initiated. Rudwaleit et al. ${ }^{[12]}$ determined the parameters predictive of major clinical response [Bath Ankylosing Spondylitis Disease Activity Index (BASDAI) improvement of at least $50 \%$ (BASDAI 50)] as the presence of active spinal inflammation on magnetic resonance imaging (MRI), shorter disease duration, and higher $\mathrm{C}$-reactive protein (CRP) values [level of evidence IIb]. According to the data from the British Society for Rheumatology Biologics Register (BSRBR), patients with higher levels of inflammatory markers at baseline responded better to anti-TNF therapy [level of evidence IIb]. ${ }^{[13]}$ In an open label phase III study of adalimumab (ADA), younger age, higher acute phase response, and HLAB27 positivity were reported to be the predictors of better clinical response. ${ }^{[14]}$

Extra-articular manifestations and comorbid conditions should be taken into consideration in treatment selection. Major extra-articular manifestations include uveitis, inflammatory bowel disease (IBD), cutaneous findings, osteopenia and osteoporosis along with cardiac, pulmonary, and renal involvement. ${ }^{[15]}$ In a meta-analysis of patients treated with the anti-TNF inhibitors etanercept (ETA) and infliximab (INF), a decrease in the incidence of uveitis was noted as compared with the placebo [level of evidence Ia]. ${ }^{[16]}$ It has also been confirmed in a retrospective analysis that anti-TNF antibodies reduce the incidence of uveitis [level of evidence III]. ${ }^{[17]}$

In a meta-analysis evaluating the incidence of IBD (new onset or flare-up) in AS patients treated with TNF-inhibitors, incidences (per 100 patient-years) were found to be $0.2,2.2,2.3$, and 1.3 for patients treated with INF, ETA, ADA and placebo, respectively ${ }^{[18]}$ No significant difference was reported between all three anti-TNF agents and the placebo; however, when evaluated separately, the incidence was found to be lower with INF [level of evidence Ia]. ${ }^{[18]}$ As exposure to ADA is of a shorter duration, there is less data available; however, it has been observed in an open-label study that it is beneficial in patients with IBD. Infliximab and ADA have been licensed in the US and Europe for Crohn's disease, and INF has also been licensed for ulcerative colitis and pediatric Crohn's disease. ${ }^{[15]}$ In Turkey, INF and ADA have been licensed for IBD.

Osteoporosis and osteopenia are common conditions accompanying AS even in the early stages of the disease. They are associated with an increase in bone turnover markers, proinflammatory cytokines, and acute phase response. Assessment of bone mineral density (BMD) by dual X-ray absorptiometry in patients with AS has certain limitations. Spinal measurements are not reliable due to new bone formations, particularly in advanced cases. Femur neck BMD is reduced and is correlated with increased vertebral fracture risk. Therefore, measuring the femur neck BMD appears to be a more suitable method for the assessment of osteoporosis, osteopenia, and fracture risk in patients with AS. ${ }^{[19]}$ There are few studies on treatment alternatives for osteoporosis in AS. There is evidence suggesting that control of disease activity in rheumatoid arthritis, Crohn's disease, and spondyloarthropathies prevents bone loss. Recent studies have demonstrated the beneficial effects of antiTNF drugs on bone density. ${ }^{[15,19]}$ In their randomized, controlled study, Visvanathan et al. ${ }^{[20]}$ reported an increase in vertebral and hip BMD in patients receiving INF [level of evidence Ib].

The strength of this recommendation is $9.47 \pm 0.64$.

2. Extra-articular involvements should be monitored and treated in collaboration with related specialties.

A heterogeneous group of disorders is listed under the heading of seronegative spondyloarthropathy (SpA). Ankylosing spondylitis, psoriatic arthritis, IBD, reactive arthritis, undifferentiated $\mathrm{SpA}$, and juvenile SpA are a group of overlapping conditions associated with complex clinical involvements. ${ }^{[21]}$ Patients may present with several clinical manifestations. This should always be kept in mind during treatment planning, and the physician should be alert for extra-articular findings and comorbid conditions. Involvements such as uveitis, psoriasis, and IBD, which are included in the ASAS classification criteria for $\mathrm{SpA},{ }^{[22]}$ should be monitored in collaboration with related specialties. In addition, osteoporosis and fractures, cardiovascular, pulmonary, and renal diseases require a multidisciplinary approach (Expert opinion, level of evidence IV).

\section{The strength of this recommendation is $9.87 \pm 0.35$.}

3. By considering the clinical presentation and ASAS core set, the follow-up of patients should include patient history, clinical parameters, laboratory tests, and imaging findings. The frequency of follow-up 


\begin{tabular}{|ll|}
\hline Table 3. Assessment of SpondyloArthritis International Society core set ${ }^{[22]}$ \\
\hline Domain & Instrument \\
\hline Function & BASFI \\
Pain & NRS/VAS (last week/spine/at night due to AS) \\
& NRS/VAS (last week/spine/due to AS) \\
Spinal mobility & Chest expansion \\
& Modified Schober \\
& Occiput to wall \\
& Cervical rotation \\
& Lateral spinal flexion or BASMI \\
Patient global & NRS/VAS (global disease activity last week) \\
Peripheral joints and entheses & Number of swollen joints (44-joint count) \\
& Validated enthesitis scores, such as MASES, San Francisco and Berlin \\
Spinal X-ray & Lateral lumbar spine and lateral cervical spine \\
Stiffness & NRS/VAS (duration of morning stiffness/spine/last week) \\
Acute phase response & C-reactive protein or erythrocyte sedimentation rate \\
Fatigue & Fatigue question BASDAI \\
\hline AS: Ankylosing spondylitis; BASDAI: Bath Ankylosing Spondylitis Disease Activity Index; BASFI: Bath Ankylosing Spondylitis \\
Functional Index; BASMI: Bath Ankylosing Spondylitis Metrology Index; MASES: Maastricht Ankylosing Spondylitis Enthesitis Score; \\
NRS: Numerical rating scale (0-10); VAS: Visual analog scale (0-100). \\
\hline
\end{tabular}

should be decided according to the severity of disease and symptoms along with drug treatment.

The Assessment of SpondyloArthritis International Society (ASAS; formerly Assessment in Ankylosing Spondylitis) is a group which started working in 1995. The principle goal of ASAS is to improve the outcome of patients with spondyloarthropathies. This essential goal includes increasing the awareness of spondyloarthropathies, facilitating early diagnosis, developing and validating assessment tools, and evaluating treatment modalities. Core sets were developed by ASAS for both clinical record keeping and disease-controlling anti-rheumatic treatments (table 3). In addition, ASAS20, ASAS40 and ASAS 5/6 improvement along with ASAS partial remission criteria were developed for the treatment response. ${ }^{[22]}$ We also use these ASAS core set parameters in the TLARFollow-up Program (TLAR-FP).

The Assessment of SpondyloArthritis International Society developed the Ankylosing Spondylitis Disease
Activity Score (ASDAS) as a novel index for the assessment of disease activity. Several parameters were evaluated for the new index, and a consensus was reached on the current version which includes spinal pain (BASDAI question 2), patient's global assessment, peripheral pain and swelling (BASDAI question 3), duration of morning stiffness (BASDAI question 6), and CRP $(\mathrm{mg} / \mathrm{L})$ or $\mathrm{ESR}(\mathrm{mm} / \mathrm{h}$; table 4). The performance of ASDAS is better and more discriminative than those of the BASDAI and CRP [level of evidence IIb]. ${ }^{[23,24]}$ In one study investigating construct validity and responsiveness of ASDAS, it was found in SpA patients treated with anti-TNF agents that changes in ASDAS correlated with changes in the BASDAI, CRP, and Berlin MRI score, and ASDAS had a higher responsiveness than the BASDAI and CRP [level of evidence IIb]. ${ }^{[25]}$

In the last decade, spine and sacroiliac joint MRI studies have provided significant contributions to the understanding and early diagnosis of the disease.

Table 4. Ankylosing spondylitis disease activity score ${ }^{[22]}$

ASDASCRP: $0.121 \mathrm{x}$ total back pain $+0.110 \mathrm{x}$ patient global $+0.073 \mathrm{x}$ peripheral pain/swelling $+0.058 \mathrm{x}$ duration of morning stiffness $+0.579 \times \operatorname{Ln}(\mathrm{CRP}+1)$

ASDASESR: $0.113 \mathrm{x}$ patient global $+0.293 \mathrm{x} \sqrt{\mathrm{ESR}}+0.086 \mathrm{x}$ peripheral pain/swelling $+0.069 \mathrm{x}$ duration of morning stiffness +0.079 $\mathrm{x}$ total back pain

ASDASCRP is preferred, but the ASDASESR can be used in case CRP data are not available (CRP in mg/L; all patient assessments on a $10 \mathrm{~cm}$ scale).

ASDAS: Ankylosing Spondylitis Disease Activity Score; CRP: C-reactive protein; ESR: Erythrocyte sedimentation rate. 
Sacroiliac joint MRI has earned its place in the classification criteria of axial spondyloarthropathies. Although MRI has not been included in the ASAS core set, it is used as an objective outcome measure both in daily practice and clinical studies as it provides objective evidence of inflammation. ${ }^{[22]}$

\section{Strength of this recommendation is $9.33 \pm 1.18$.}

4. Pharmacological and non-pharmacological treatments should be used in combination for optimal management of AS.

There are no head-to-head comparison studies of pharmacological and non-pharmacological treatments. These two treatment modalities complement each other during the initiation and throughout the course of the disease with the non-pharmacological methods deemed to be crucial. However, there is not enough data regarding non-pharmacological treatment methods since most studies have focused on investigating pharmacological methods. ${ }^{[5]}$

\section{Strength of this recommendation is $9.80 \pm 0.56$.}

5. Non-pharmacological treatment methods principally include patient education and a regular exercise program (floor and water exercises). In addition, balneotherapy and spa therapy along with physical treatment modalities and occupational therapy are also included.

- Patient associations and help groups may be useful.

The experts are in agreement that despite all of the developments in pharmacological treatments, physical treatment methods remain one of the essential treatment modalities in the management plan of AS. ${ }^{[26]}$

Patient education has increasingly become important in rehabilitation. Patients are not comfortable with uncertainties related to their future. Education and behavioral therapy aim to improve the self-management skills of the patients. When patients are informed about their needs and self-care skills, their motivation increases while their anxiety decreases. ${ }^{[27]}$ There has not been enough research conducted on education in patients with AS. In a relatively old study investigating the effectiveness of group education in patients with arthritis, it was noted that a self-management course demonstrated short-term positive effects on self-efficacy and psychological well-being [level of evidence III]. ${ }^{[28]}$ There is an analysis showing that an education program is cost effective in AS. Program costs per patient were found to be $€ 117$ for 10 participants per course and $€ 186$ for six participants per course. This resulted in a savings of $€ 2500$ in indirect costs which more than compensated for the costs of the program. ${ }^{[29]}$ In a Cochrane analysis evaluating the effectiveness of selfmanagement education programs concerning chronic conditions (arthritis, diabetes, hypertension, chronic pain), 17 randomized controlled trials (RCTs) including 7442 patients were analyzed. ${ }^{[30]}$ It was concluded that these programs led to small, short-term improvements in the patient's self-efficacy and self-rated health. The frequency of aerobic exercise also increased in these patients. Although clinically not significant, mild improvements were also noted in pain, disability, fatigue, and depression levels. No significant differences were found in quality of life, frequency of physician visits, or time spent in hospital. No adverse events were reported [level of evidence Ia]. ${ }^{[30]}$ In a recent prospective RCT evaluating the effectiveness of a non-generic, diseasespecific education program in Turkey, patients with AS underwent an education program led by peers diagnosed with $\mathrm{AS}^{\left[{ }^{[31]}\right.}$ In that particular study, no change was observed in the quality of life of the patients following four weeks of education. However, knowledge about the disease increased both in the active education group and in the control group, which was only provided with an educational brochure [level of evidence $\mathrm{Ib}] .^{[31]}$

Exercise therapy (floor or water) in AS aims to maintain and improve the mobility of the spine and joints, strengthen lower extremity, back, and abdominal muscles, provide relaxation, and increase physical fitness. ${ }^{[27]}$ A Cochrane analysis reviewed 763 patients from 11 randomized or semi-randomized studies with physiotherapy in at least one arm. ${ }^{[32]}$ Pain, stiffness, spinal mobility, physical function, and patient's global assessment were used as outcome measures. In four studies, exercises either performed alone at home or under supervision were found to be superior to no exercise in terms of spinal mobility and physical function. Group physiotherapy was found to be superior to personal home exercise in three studies. ${ }^{[32]}$ After the Cochrane review period ended in 2006, beneficial effects of mobilization and home exercises on chest expansion, spinal mobility, and physical function have also been reported. ${ }^{[27]}$ In a study evaluating the effects of exercise on pulmonary functions, significant improvement was noted in pain, chest expansion, pulmonary function parameters, and six-minute walking tests in the exercise group compared with the control group. ${ }^{[33]}$ In that particular study, the Global Posture Reeducation (GPR) method 
and conventional exercises were also compared, and greater improvements were noted in specific pulmonary function parameters by the GPR method [level of evidence IIa]. ${ }^{[33]}$ In their RCT, Karapolat et al. ${ }^{[34]}$ demonstrated that the addition of swimming and walking to conventional exercises provided further beneficial effects on Nottingham Health Profile scores and pulmonary functions [level of evidence Ib]. In another prospective RCT, Widberg et al. ${ }^{[35]}$ reported that individualized manual mobilization and home exercises performed one hour every week for eight weeks had significant beneficial effects on chest expansion, posture, and spinal mobility [level of evidence Ib].

Balneotherapy is a treatment method which is commonly used in Europe, but not in the United States. ${ }^{[27]}$ There is an RCT by van Tubergen in a Cochrane review which demonstrates in 120 patients that spa therapy and weekly group exercise is superior to exercise alone in terms of pain and well-being in AS. ${ }^{[32]}$ In an RCT by Yurtkuran et al., ${ }^{[36]}$ in which spa and NSAID therapies were compared, it was found that the combination of spa and NSAID therapies was superior in alleviating symptoms and improving spinal mobility compared with the use of NSAID alone [level of evidence Ib]. In an RCT by Altan et al., ${ }^{[37]}$ it was reported that there was a significant improvement in disease activity and functional parameters following a period of balneotherapy; however, the effect decreased after six months [level of evidence Ib].

Among 29 RCTs on balneotherapy included in a meta-analysis by Falagas et al., ${ }^{[38]} 22$ were conducted on rheumatic diseases, four of which were performed on AS [level of evidence Ia]. Current evidence supports the effectiveness of balneotherapy. However, the data is insufficient to draw definite conclusions; thus, more RCTs are needed. Eight of the studies included in the meta-analysis by Falagas et al. ${ }^{[38]}$ were conducted in Turkey. In the light of this evidence, large-scale RCTs on balneotherapy and spa treatment should be performed in our country which is rich in thermal springs. As the number of studies is increased, an increasing number of patients will have the chance to benefit from the potential positive effects of regular balneotherapy.

Patients with arthritis may also benefit from the therapeutic physiological effects of thermal, electrical, light, sound, and magnetic energy. There is no systematic review of thermotherapy in AS, but there is a small-scale observational study reporting the beneficial effects of infrared baths on pain, stiffness, and fatigue [level of evidence III] ${ }^{[39]}$ There is also an RCT reporting the beneficial, but statistically insignificant, effect of transcutaneous electrical nerve stimulation (TENS) on pain. ${ }^{[27]}$ In an RCT by Gürçay et al., ${ }^{[40]}$ the positive effects of a Stanger bath (a combination of electrotherapy and hydrotherapy) on spinal mobility, functional capacity, disease activity, and quality of life were demonstrated [level of evidence Ib]. Although there are no controlled studies about the effects of massage therapy in AS, it is known to be a safe method which reduces pain. ${ }^{[27]}$

In an RCT evaluating the effects of occupational therapy (OT) in AS, OT was performed on 14 out of 27 patients receiving anti-TNF while 13 served as the control group. ${ }^{[41]}$ While clinical findings were similar at baseline, significant improvements were noted in the BASFI, BASDAI, the Bath Ankylosing Spondylitis Metrology Index (BASMI), the Short Form-36, and pain scores after 16 weeks in the OT group. Patients in this group were found to use self-management methods associated with joint protection and energy preservation more frequently [level of evidence $\mathrm{Ib}]{ }^{[41]}$

Strength of this recommendation is $9.47 \pm 0.64$.

The categories with the evidence of studies regarding non-pharmacological methods are summarized in table 5 .

6. Non-steroidal anti-inflammatory drugs (NSAIDs) are the first-line treatment to alleviate pain and stiffness.

- In patients with a higher risk for gastrointestinal side effects, a combination of an NSAID and a gastroprotective agent or a selective COX-II inhibitor can be used.

Non-steroidal anti-inflammatory drugs are used in AS not only because of their analgesic effect, but also because of their high anti-inflammatory and probable anti-osteoproliferative potential. Normally,

\begin{tabular}{lc}
$\begin{array}{l}\text { Table 5. Categories of evidence } \\
\text { pharmacological methods }\end{array}$ & $\begin{array}{c}\text { regarding } \\
\text { Category of } \\
\text { evidence }\end{array}$ \\
\hline Intervention & Ia \\
\hline $\begin{array}{l}\text { Physical activity, exercises (floor and water) } \\
\text { Balneotherapy and spa therapy }\end{array}$ & Ia \\
Electro-physical modalities & Ib \\
Stanger bath (diadynamic currents) & III \\
Infrared sauna & Ia \\
Patient education & Ib \\
Occupational therapy & IV \\
Patient associations, help groups &
\end{tabular}


the optimal effects of NSAIDs begin within one or two weeks, but sometimes a longer treatment period may be required to decide on the optimal drug and proper dosage. At least two or three drugs in the NSAID family should be tried at optimal dosage. Individual differences may be observed in terms of response to NSAIDs ${ }^{[42-44]}$ which reduce spinal pain and peripheral joint pain along with improving function. In a celecoxib study in which patients were monitored for two years, findings suggested that continuous drug use delayed radiological progression compared with intermittent drug use (on-demand use). However, this is the first study suggesting the disease-modifying effect of continuous treatment, and confirmation by further studies is required [level of evidence Ib]. ${ }^{[45]}$

It has been recommended by the $3 \mathrm{E}$ initiative that NSAIDs should be used as needed for alleviating symptoms of active disease. However, in patients with persistent disease activity, it has also been recommended that NSAIDs may need to be used continuously keeping in mind that the risk of adverse effects, including cardiovascular toxicity, might also increase based on level Ib evidence. ${ }^{[10]}$

\section{Strength of this recommendation is $8.87 \pm 1.77$.}

7. For pain control, analgesics such as paracetamol and opioids may be considered when NSAIDs are inadequate, contraindicated, and/or poorly tolerated.

There are no prospective studies evaluating paracetamol and simple analgesics in AS. Gastrointestinal toxicity is not greater than the placebo according to studies conducted in musculoskeletal conditions [level of evidence Ia]. ${ }^{[5]}$ Opioid use for chronic non-cancer pain conditions (osteoarthritis, rheumatoid arthritis, neuropathic pain, phantom extremity pain, fibromyalgia) was evaluated in a metaanalysis of 41 randomized studies which included 6019 patients. ${ }^{[4]}$ Opioids were found to be superior to the placebo in terms of improving pain and function. Strong opioids were found to be superior to naproxen and nortriptyline for pain. Among adverse effects, only nausea and constipation were found to be clinically and statistically significant [level of evidence Ia]. Although popular thought suggests that their use in chronic pain would not be associated with misuse or abuse, it is not possible to draw unequivocal conclusions since the studies have short durations, and their designs do not allow for assessment of this aspect. ${ }^{[46]}$

Strength of this recommendation is $8.73 \pm 2.09$.
8. Corticosteroid injections can be administered to local sites of inflammation. There is not enough evidence supporting the use of systemic steroids in axial disease.

There are no controlled studies investigating the effects of systemic glucocorticoids (GC) in AS. In the light of uncontrolled clinical experience, it can be stated that, in contrast to their effects in rheumatoid arthritis, GC (at least in small and moderate doses) do not improve symptoms and structural damage in AS.

Pulse steroid therapy is a specific treatment method in which $\geq 250 \mathrm{mg}$ of prednisone equivalent per day is often administered intravenously for a short period of time ( $\leq 5$ days). There are a few observational and open studies reporting the effects of intravenous pulse GC therapy. Intra-articular GC treatment, including injections in the hip and sacroiliac joints, provides short-term improvement. Intra- or peri-articular steroid injections have been shown to provide beneficial effects for pain associated with sacroiliitis in small RCTs [level of evidence $1 b$ ]. An MRI-guided or computed tomography-guided injection of sacroiliac joints prolongs the effectiveness of treatment. There are no clinical trials on their effects on peripheral arthritis or enthesitis, although it is known by experts that they may provide benefits in selected cases, The potential complication of tendon rupture should not be overlooked when considering pulse steroid therapy. ${ }^{[4]}$

\section{Strength of this recommendation is $9.20 \pm 2.04$.}

9. There is no evidence regarding the effect of disease-modifying agents (including sulfasalazine: SSZ, methotrexate: MTX) on axial disease, but SSZ may be used in peripheral arthritis.

Sulfasalazine is a disease-modifying agent that has been most thoroughly investigated in AS. Considering the results of these studies, SSZ has not been recommended for axial involvement, but it has been recommended for patients with peripheral arthritis [level of evidence Ia]. ${ }^{[48,49]}$ However, all of these studies included patients with long disease duration. Studies regarding the effect of SSZ on patients with short disease duration are needed. In a multi-center, placebo-controlled, six-month study conducted of in undifferentiated SpA patients with a disease duration of $<5$ years, SSZ at a dose $2 \mathrm{~g} /$ day was found to be superior to the placebo on spinal pain and morning stiffness in the group with inflammatory back pain without peripheral arthritis. No significant difference 
was noted in other outcome measures [level of evidence Ib]. ${ }^{[50]}$ Kabasakal et al. ${ }^{[1]}$ used dynamic MRI when comparing MTX, SSZ, and MTX+SSZ treatments in 55 patients with active sacroiliitis and found that SSZ provided a better response, although it was not statistically significant. It has been suggested that a better treatment response may be obtained by SSZ as a disease-modifying agent, especially in the early period compared with MTX and MTX+SSZ [level of evidence IIb] ${ }^{[51]}$ In an RCT investigating the effect of SSZ on uveitis, SSZ was reported to reduce the frequency of acute anterior uveitis [level of evidence Ib]. ${ }^{[52]}$

No beneficial effects of MTX were observed in three RCTs [level of evidence Ib]. In the studies on MTX, it was used at a dose of 7.5-10 mg/week orally and at a dose of $12.5 \mathrm{mg} /$ week intramuscularly. Considering the fact that the lack of effectiveness might be due to insufficient dosage, subcutaneous MTX $20 \mathrm{mg} /$ week was used in a more recent study. In that particular open study, MTX was administered for 16 weeks in 20 patients with active AS. The patients were administered with $15 \mathrm{mg} /$ week MTX subcutaneously for the initial four weeks followed by $20 \mathrm{mg} /$ week MTX subcutaneously in the subsequent 12 weeks. No significant difference was noted compared to the baseline in axial findings, clinical parameters, or CRP levels other than a small but insignificant reduction in the number of swollen joints [level of evidence III]. ${ }^{[53]}$

In a six-month study in which $20 \mathrm{mg} /$ day leflunomide was used, improvement was noted in peripheral arthritis, but no improvement was found in axial symptoms [level of evidence III]. ${ }^{[54]}$

There is little evidence for other drugs. Beneficial effects of intravenous pamidronate on axial pain and function have been reported [level of evidence III]; however, its effect on peripheral disease has not been assessed, which is a major limitation. Future RCTs are needed to address these questions. ${ }^{[10]}$

\section{Strength of this recommendation is $7.80 \pm 2.54$.}

10. Anti-TNF treatment should be given when the activity of the disease continues despite conventional treatments according to the ASAS recommendations. There is no evidence that approves of the usage of DMARDs before, or together with, anti-TNF treatment in patients with axial disease.

Evidence for the use of INF, ETA and ADA is classified as level $1 \mathrm{~b}$. Recent evidence has demonstrated that the effects of anti-TNF treatment appear rapidly, in some cases within two weeks of starting treatment, and remain as long as the treatment is continued. Relapse occurs in most of the patients after discontinuation of therapy. Re-initiation of treatment is safe and effective. There is no evidence to support the benefit of adding MTX to the treatment in AS. Anti-TNF agents are generally well tolerated. There are studies demonstrating the long-term efficacy and safety of anti-TNF drugs [level of evidence III]. Nevertheless, questions remain regarding optimal dosage, treatment duration, and their effects on disease progression. ${ }^{[26,55-61]}$ A consensus report was published by ASAS regarding the use of anti-TNF agents in 2003, and it was updated in 2006. Also, ASAS recently released an update on their usage in axial spondyloarthropathies in 2010. These recommendations should be taken into account when using anti-TNF drugs. ${ }^{[62]}$

In summary, INF, ETA, and ADA have been found to have similar clinical efficacy. Anti-TNF treatment has been found to be highly effective compared with traditional treatment methods; however, it is very expensive. Despite its high cost, it may also prove to be economical as the patients' function and productivity are maintained. Thus, pharmacoeconomic studies are needed. Analyses of cost effectiveness in real-life settings have been performed for anti-TNF agents (ETA, INF, and ADA) in rheumatoid arthritis, AS, and psoriatic arthritis patients using the Health Assessment Questionnaire (HAQ). The HAQ score has been selected as it is an excellent predictor of work absenteeism, morbidity, and mortality. It has been demonstrated that the HAQ score is reduced by treatment, and this reduction continues for three to five years. The number needed to treat (NNT) with anti-TNF to achieve minimal significant change in the HAQ score has been found to be two, and this appears to be a good and sufficient result [level of evidence IIb]. ${ }^{[63]}$ Data regarding NNT for clinical benefit has been reported to be between one and two. ${ }^{[55]}$

Golimumab is another anti-TNF agent used in the management of AS. ${ }^{[64]}$ However, it has not yet been licensed in Turkey.

Strength of this recommendation is $8.80 \pm 1.61$.

11. Total hip arthroplasty should be applied to patients with refractory pain or disability and radiographic structural damage which is unrelated to age.

Spinal surgical methods, such as corrective osteotomy and stabilization procedures, may be helpful in selected patients. 
The best evidence regarding hip arthroplasty is level IV. Reduction in pain and improvement in function have been observed in prospective cohorts. Age and gender are determinants of revision rates that are relatively low. Frequency of heterotopic ossification is not higher than in other conditions. This may be associated with the use of NSAIDs. According to expert opinion, preoperative cessation of NSAIDs is not necessary, and it has been reported that NSAID usage does not affect perioperative hemorrhage. There is not much difference between cemented and non-cemented prostheses in terms of durability and complications. However, non-cemented prostheses are preferred in young patients since future revisions are easier. ${ }^{[5]}$ In a recent, retrospective analysis of 92 patients who underwent cementless arthroplasty, survival rates were found to be $98.8 \%$ at five years and $85.8 \%$ at 8.5 years. The heterotopic ossification rate was reported as $13 \%$ in that cohort. ${ }^{[26]}$

Spinal surgery may be required in conditions including kyphosis, loss of horizontal vision, painful spinal pseudarthrosis or Anderson lesion, painful and unstable spinal fractures, and in the occurrence of neurological complications such as spinal stenosis, myelopathy, and cauda equina syndrome. ${ }^{[5]}$ In a study in which wedge osteotomy was performed to reduce thoracolumbar kyphosis in 20 patients, a mean reduction of $17^{\circ}$ was noted in kyphosis, and the outcome was reported as "good" in 16 patients and "moderate" in four patients at the end of one year. ${ }^{[26]}$

\section{Strength of this recommendation is $8.80 \pm 2.11$.}

12. Spinal pain of sudden onset which cannot be directly attributed to inflammation should be investigated.

The assessment and opinion of a spinal surgeon should be sought in the presence of an acute vertebral fracture.

Osteoporosis and osteopenia are other well-known complications of AS. Fractures may occur even by minor trauma in osteoporotic and fused vertebra. ${ }^{[19]}$ Vertebral fractures further increase spinal deformity (hyperkyphosis), and spinal cord injuries may also occur due to vertebral fractures. Despite these facts, most physicians fail to assess the patient regarding this respect in routine practice. ${ }^{[19]}$ In addition, vertebral fractures are also difficult to diagnose for several reasons. First, only one out of every three or four vertebral fractures is associated with typical clinical symptoms and findings. Moreover, even symptomatic, clinical vertebral fractures may be overlooked since acute, chronic back pain is common in patients with AS. This pain may be attributed to disease activity; thus, fracture may not be considered in the differential diagnosis. Secondly, vertebral fractures in radiographs may also be overlooked. Thirdly, in addition to vertebral body fractures, posterior arch and pedicle fractures, which are rare in postmenopausal osteoporosis and hard to diagnose because of their location, may also occur in AS. Fourthly, the image quality of the thoracic region is often low due to the ribs and soft tissues, and screening studies provide data regarding lumbar rather than thoracic vertebra. Therefore, the thoracic region may be overlooked in prevalence studies on vertebral fractures. Finally, although a consensus regarding the definition of vertebral fracture has started to form, there is no widely accepted gold standard yet. Thus, prevalence and incidence rates are subject to change based on the definition. ${ }^{[65]}$

The presence of a vertebral fracture should certainly be considered in patients with a high risk for osteoporosis and fracture such as postmenopausal woman, patients with low body weight, or those with a history of previous fracture or a maternal history of hip fracture. Also, those patients using glucocorticoids or those who are immobilized are also at high risk as well as patients in AS-specific high risk groups such as those with high disease activity, persistent disease activity, long-standing disease, occiput wall distance $>0$, or persistent pain following minimal trauma. Imaging techniques are indicated in cases of persistent pain to prevent delay in diagnosis and treatment. ${ }^{[63]}$ As emphasized previously, the assessment and opinion of a spinal surgeon should be sought in the presence of an acute vertebral fracture. Other than fractures, differential diagnosis should also include infections (vertebral, discogenic, or epidural) as well as metastatic and primary malignancies. Appropriate laboratory and imaging methods should also be employed. ${ }^{[6]}$

Strength of this recommendation is $8.67 \pm 2.26$.

In conclusion, this guideline was based on ASAS/EULAR recommendations, and some minor additions and changes have been made to these recommendations. It is encouraging that these additions and changes overlap with a recently published 2010 update of ASAS/EULAR recommendations without any contradictions, and the recommendations in this guideline have sufficient strength levels. We hope that these recommendations are widely used among our colleagues. 


\section{Appendix 1. TRASD Ankilozan Spondilit Ulusal Tedavi Önerileri}

1. Tedavi, hastanın özelliklerine göre planlanmalıdır. Bu planlama;

- Hastalığın mevcut belirti ve bulguları (aksiyel, periferik, entezal, ekstraartiküler tutulum)

- Semptom ve klinik bulgular ve prognostik göstergelerin düzeyi (hastalık aktivitesi/inflamasyon, ağrı, işlevsellik, aktivite ve katılımın kısıtlanması, yapısal hasar, kalça tutulumu ve spinal deformiteler)

- Demografik ve tıbbi özellikler (yaş, cinsiyet, eşlik eden hastalıklar, diğer ilaçlar)

- Hastanın istek ve beklentileri dikkate alınarak yapılmalıdır.

2. Eklem dışı tutulumlar, ilgili uzmanlık alanları ile işbirliği içinde izlenmeli ve tedavi edilmelidir.

3. Hasta izlemi, klinik tablo ve ASAS çekirdek seti dikkate alınarak, hastanın öyküsünü, klinik parametreleri, laboratuvar testleri ve görüntüleme bulgularını içermelidir. İzlem sıklığına, hastalığın ve semptomların şiddetine ve ilaç tedavisine göre karar verilmelidir.

4. Ankilozan Spondilit'in ideal tedavisi için farmakolojik ve nonfarmakolojik yöntemler birlikte uygulanmalıdır.

5. Nonfarmakolojik tedavi yaklaşımları; başta hasta eğitimi ve düzenli egzersiz programı (yer ve su içi egzersizleri) olmak üzere balneoterapi ve spa terapisi, fizik tedavi modaliteleri, iş ve uğraşı tedavisini içerir.

- Hasta dernekleri ve yardım grupları yararlı olabilir.

6. NSAİ ağrı ve tutukluğu gidermede ilk basamaktır.

- Gastrointestinal yan etki yönünden daha yüksek risk taşıyan hastalarda, NSAİ ve gastroprotektif ajan kombinasyonu veya selektif COX-II inhibitörü verilebilir.

7. Ağrı kontrolünde, NSAİ’lerin yetersiz, kontrendike olduğu veya iyi tolere edilemediği durumlarda, parasetamol ve opioidler gibi analjezikler düşünülebilir.

8. Lokal inflamasyon bölgelerine kortikosteroid injeksiyonu yapılabilir. Aksiyel hastalıkta sistemik steroidlerin kullanımına dair yeterli kanıt yoktur.

9. Hastalık modifiye edici ajanların (sulfasalazin: SSZ, metotreksat: MTX dahil) aksiyel hastalığa etkisine dair kanıt yoktur. Sulfasalazin periferal artritte kullanılabilir.

10. ASAS önerilerine göre konvansiyonel tedaviye rağmen hastalık aktivitesi süren olgularda anti-TNF tedavi verilmelidir. Aksiyel tutulumlu hastalarda anti-TNF öncesi veya birlikte DMARD kullanma zorunluluğunu destekleyen kanıt yoktur.

11. Total kalça artroplastisi, refrakter ağrısı veya özürlülüğü olan ve radyolojik olarak yapısal hasarı bulunan hastalarda, yaşa bağlı olmaksızın düşünülmelidir. Seçilmiş olgularda düzeltici osteotomi ve stabilizasyon işlemleri gibi spinal cerrahi yöntemleri yararlı olabilir.

12. Hastalığın seyri esnasında aniden gelişen ve doğrudan inflamasyona bağlanamayan omurga ağrıları araştırılmalıdır. Akut vertebra kırığı varlığında omurga cerrahının değerlendirmesi ve görüşü mutlaka alınmalıdır.

ASAS: Spondilartrit Uluslararası Değerlendirme Topluluğu (The ASsessment in Ankylosing Spondylitis International Society); COX: Siklooksijenaz; DMARD: Hastalık modifiye edici antiromatizmal ilaç (Disease modifying anti-rheumatic drug); NSAİ: Non-steroidal anti-inflamatuar ilaç; TNF: Tümör nekroz faktör. 
The Turkish version of "Turkish League Against Rheumatism (TLAR) National Recommendations for the Management of Ankylosing Spondylitis" is available at our website (www.trasd.org.tr).

\section{Declaration of conflicting interests}

The authors declared no conflicts of interest with respect to the authorship and/or publication of this article.

\section{Funding}

The authors received no financial support for the research and/or authorship of this article.

\section{REFERENCES}

1. Onen F, Akar S, Birlik M, Sari I, Khan MA, Gurler O, et al. Prevalence of ankylosing spondylitis and related spondyloarthritides in an urban area of Izmir, Turkey. J Rheumatol 2008;35:305-9.

2. Bodur H, Ataman S, Buğdaycı DS, Rezvani A, Nas K, Uzunca K, et al. Description of the registry of patients with ankylosing spondylitis in Turkey: TRASD-IP. Rheumatol Int 2010. [Epub ahead of print]

3. Bodur H, Ataman S, Rezvani A, Buğdaycı DS, Cevik R, Birtane $\mathrm{M}$, et al. Quality of life and related variables in patients with ankylosing spondylitis. Qual Life Res 2011;20:543-9.

4. Zochling J, van der Heijde D, Dougados M, Braun J. Current evidence for the management of ankylosing spondylitis: a systematic literature review for the ASAS/ EULAR management recommendations in ankylosing spondylitis. Ann Rheum Dis 2006;65:423-32.

5. Zochling J, van der Heijde D, Burgos-Vargas R, Collantes E, Davis JC Jr, Dijkmans B, et al. ASAS/EULAR recommendations for the management of ankylosing spondylitis. Ann Rheum Dis 2006;65:442-52.

6. Kiltz U, van der Heijde D, Mielants H, Feldtkeller E, Braun J; PARE/EULAR patient initiative group. ASAS/ EULAR recommendations for the management of ankylosing spondylitis: the patient version. Ann Rheum Dis 2009;68:1381-6.

7. Braun J, van den Berg $\mathrm{R}$, Baraliakos X, Boehm $\mathrm{H}$, Burgos-Vargas R, Collantes-Estevez E, et al. 2010 update of the ASAS/EULAR recommendations for the management of ankylosing spondylitis. Ann Rheum Dis 2011;70:896-904.

8. Dougados $M$, Betteridge $N$, Burmester GR, Euller-Ziegler L, Guillemin F, Hirvonen J, et al. EULAR standardised operating procedures for the elaboration, evaluation, dissemination, and implementation of recommendations endorsed by the EULAR standing committees. Ann Rheum Dis 2004;63:1172-6.

9. Oxman AD, Guyatt GH. Validation of an index of the quality of review articles. J Clin Epidemiol 1991;44:1271-8.
10. Sidiropoulos PI, Hatemi G, Song IH, Avouac J, Collantes E, Hamuryudan V, et al. Evidence-based recommendations for the management of ankylosing spondylitis: systematic literature search of the $3 \mathrm{E}$ Initiative in Rheumatology involving a broad panel of experts and practising rheumatologists. Rheumatology (Oxford) 2008;47:355-61.

11. Stone MA, Pomeroy E, Keat A, Sengupta R, Hickey S, Dieppe $\mathrm{P}$, et al. Assessment of the impact of flares in ankylosing spondylitis disease activity using the Flare Illustration. Rheumatology (Oxford) 2008;47:1213-8.

12. Rudwaleit M, Schwarzlose S, Hilgert ES, Listing J, Braun J, Sieper J. MRI in predicting a major clinical response to anti-tumour necrosis factor treatment in ankylosing spondylitis. Ann Rheum Dis 2008;67:1276-81.

13. Lord PA, Farragher TM, Lunt M, Watson KD, Symmons DP, Hyrich KL; BSR Biologics Register. Predictors of response to anti-TNF therapy in ankylosing spondylitis: results from the British Society for Rheumatology Biologics Register. Rheumatology (Oxford) 2010;49:563-70.

14. Rudwaleit M, Claudepierre P, Wordsworth P, Cortina EL, Sieper J, Kron M, et al. Effectiveness, safety, and predictors of good clinical response in 1250 patients treated with adalimumab for active ankylosing spondylitis. J Rheumatol 2009;36:801-8.

15. Elewaut D, Matucci-Cerinic M. Treatment of ankylosing spondylitis and extra-articular manifestations in everyday rheumatology practice. Rheumatology (Oxford) 2009;48:1029-35.

16. Braun J, Baraliakos X, Listing J, Sieper J. Decreased incidence of anterior uveitis in patients with ankylosing spondylitis treated with the anti-tumor necrosis factor agents infliximab and etanercept. Arthritis Rheum 2005;52:2447-51.

17. Guignard S, Gossec L, Salliot C, Ruyssen-Witrand A, Luc M, Duclos M, et al. Efficacy of tumour necrosis factor blockers in reducing uveitis flares in patients with spondylarthropathy: a retrospective study. Ann Rheum Dis 2006;65:1631-4.

18. Braun J, Baraliakos X, Listing J, Davis J, van der Heijde D, Haibel $\mathrm{H}$, et al. Differences in the incidence of flares or new onset of inflammatory bowel diseases in patients with ankylosing spondylitis exposed to therapy with anti-tumor necrosis factor alpha agents. Arthritis Rheum 2007;57:639-47.

19. Magrey M, Khan MA. Osteoporosis in ankylosing spondylitis. Curr Rheumatol Rep 2010;12:332-6.

20. Visvanathan S, van der Heijde D, Deodhar A, Wagner C, Baker DG, Han J, et al. Effects of infliximab on markers of inflammation and bone turnover and associations with bone mineral density in patients with ankylosing spondylitis. Ann Rheum Dis 2009;68:175-82.

21. Zeidler H, Amor B. The Assessment in Spondyloarthritis International Society (ASAS) classification criteria for peripheral spondyloarthritis and for spondyloarthritis in general: the spondyloarthritis concept in progress. Ann Rheum Dis 2011;70:1-3. 
22. Sieper J, Rudwaleit M, Baraliakos X, Brandt J, Braun J, Burgos-Vargas $\mathrm{R}$, et al. The Assessment of SpondyloArthritis international Society (ASAS) handbook: a guide to assess spondyloarthritis. Ann Rheum Dis 2009;68 Suppl 2:ii1-44.

23. Lukas C, Landewé R, Sieper J, Dougados M, Davis J, Braun J, et al. Development of an ASAS-endorsed disease activity score (ASDAS) in patients with ankylosing spondylitis. Ann Rheum Dis 2009;68:18-24.

24. van der Heijde D, Lie E, Kvien TK, Sieper J, Van den Bosch F, Listing J, et al. ASDAS, a highly discriminatory ASAS-endorsed disease activity score in patients with ankylosing spondylitis. Ann Rheum Dis 2009;68:1811-8.

25. Pedersen SJ, Sørensen IJ, Hermann KG, Madsen OR, TvedeN,Hansen MS, etal. Responsiveness of the Ankylosing Spondylitis Disease Activity Score (ASDAS) and clinical and MRI measures of disease activity in a 1-year follow-up study of patients with axial spondyloarthritis treated with tumour necrosis factor alpha inhibitors. Ann Rheum Dis 2010;69:1065-71.

26. Braun J, Baraliakos X. Treatment of ankylosing spondylitis and other spondyloarthritides. Curr Opin Rheumatol 2009;21:324-34.

27. Vliet Vlieland TP, Li LC. Rehabilitation in rheumatoid arthritis and ankylosing spondylitis: differences and similarities. Clin Exp Rheumatol 2009;27:S171-8.

28. Barlow JH, Barefoot J. Group education for people with arthritis. Patient Educ Couns 1996;27:257-67.

29. Krauth C, Rieger J, Bönisch A, Ehlebracht-König I. Costs and benefits of an education program for patients with ankylosing spondylitis as part of an inpatient rehabilitation programs-study design and first results. $\mathrm{Z}$ Rheumatol 2003;62:II14-6. [Abstract]

30. Foster G, Taylor SJ, Eldridge SE, Ramsay J, Griffiths CJ. Self-management education programmes by lay leaders for people with chronic conditions. Cochrane Database Syst Rev 2007;CD005108.

31. Kaya T, Atıcı Öztürk P, Göksel Karatepe A, Günaydın R. Impact of peer-led education on quality oflife and knowledge about disease in patients with ankylosing spondylitis. Rheumatology 2011;50(Suppl 2):ii2. 32.

32. Dagfinrud H, Kvien TK, Hagen KB. Physiotherapy interventions for ankylosing spondylitis. Cochrane Database Syst Rev 2008;CD002822.

33. Durmuş D, Alayli G, Uzun O, Tander B, Cantürk F, Bek Y, et al. Effects of two exercise interventions on pulmonary functions in the patients with ankylosing spondylitis. Joint Bone Spine 2009;76:150-5.

34. Karapolat H, Eyigor S, Zoghi M, Akkoc Y, Kirazli Y, Keser G. Are swimming or aerobic exercise better than conventional exercise in ankylosing spondylitis patients? A randomized controlled study. Eur J Phys Rehabil Med 2009;45:449-57.

35. Widberg K, Karimi H, Hafström I. Self- and manual mobilization improves spine mobility in men with ankylosing spondylitis-a randomized study. Clin Rehabil 2009;23:599-608.
36. Yurtkuran M, Ay A, KarakoçY.Improvement of the clinical outcome in Ankylosing spondylitis by balneotherapy. Joint Bone Spine 2005;72:303-8.

37. Altan L, Bingöl U, Aslan M, Yurtkuran M. The effect of balneotherapy on patients with ankylosing spondylitis. Scand J Rheumatol 2006;35:283-9.

38. Falagas ME, Zarkadoulia E, Rafailidis PI. The therapeutic effect of balneotherapy: evaluation of the evidence from randomised controlled trials. Int J Clin Pract 2009;63:1068-84.

39. Oosterveld FG, Rasker JJ, Floors M, Landkroon R, van Rennes B, Zwijnenberg J, et al. Infrared sauna in patients with rheumatoid arthritis and ankylosing spondylitis. A pilot study showing good tolerance, short-term improvement of pain and stiffness, and a trend towards long-term beneficial effects. Clin Rheumatol 2009;28:29-34.

40. Gurcay E, Yuzer S, Eksioglu E, Bal A, Cakci A. Stanger bath therapy for ankylosing spondylitis: illusion or reality? Clin Rheumatol 2008;27:913-7.

41. Spadaro A, De Luca T, Massimiani MP, Ceccarelli F, Riccieri V, Valesini G. Occupational therapy in ankylosing spondylitis: Short-term prospective study in patients treated with anti-TNF-alpha drugs. Joint Bone Spine 2008;75:29-33.

42. Song IH, Poddubnyy DA, Rudwaleit M, Sieper J. Benefits and risks of ankylosing spondylitis treatment with nonsteroidal antiinflammatory drugs. Arthritis Rheum 2008;58:929-38.

43. Sieper J. Can structural damage be prevented in ankylosing spondylitis? Curr Opin Rheumatol 2009;21:335-9.

44. Poddubnyy D, Song IH, Sieper J. A systematic comparison of rheumatoid arthritis and ankylosing spondylitis: nonsteroidal anti-inflammatory drugs. Clin Exp Rheumatol 2009;27:S148-51.

45. Wanders A, Heijde D, Landewé R, Béhier JM, Calin A, Olivieri I, et al. Nonsteroidal antiinflammatory drugs reduce radiographic progression in patients with ankylosing spondylitis: a randomized clinical trial. Arthritis Rheum 2005;52:1756-65.

46. Furlan AD, Sandoval JA, Mailis-Gagnon A, Tunks E. Opioids for chronic noncancer pain: a meta-analysis of effectiveness and side effects. CMAJ 2006;174:1589-94.

47. Spies CM, Burmester GR, Buttgereit F. Analyses of similarities and differences in glucocorticoid therapy between rheumatoid arthritis and ankylosing spondylitis-a systematic comparison. Clin Exp Rheumatol 2009;27:S152-8.

48. Haibel H, Specker C. Disease-modifying anti-rheumatic drugs in rheumatoid arthritis and ankylosing spondylitis. Clin Exp Rheumatol 2009;27:S159-63.

49. Chen J, Liu C. Sulfasalazine for ankylosing spondylitis. Cochrane Database Syst Rev 2005;CD004800.

50. Braun J, Zochling J, Baraliakos X, Alten R, Burmester G, Grasedyck K, et al. Efficacy of sulfasalazine in patients with inflammatory back pain due to undifferentiated spondyloarthritis and early ankylosing spondylitis: a multicentre randomised controlled trial. Ann Rheum Dis 2006;65:1147-53. 
51. Kabasakal Y, Kitapcioglu G, Yargucu F, Taylan A, Argin M, Gumusdis G. Efficacy of SLZ and MTX (alone or combination) on the treatment of active sacroiliitis in early AS. Rheumatol Int 2009;29:1523-7.

52. Benitez-Del-Castillo JM, Garcia-Sanchez J, Iradier T, Bañares A. Sulfasalazine in the prevention of anterior uveitis associated with ankylosing spondylitis. Eye (Lond) 2000;340-3.

53. Haibel H, Brandt HC, Song IH, Brandt A, Listing J, Rudwaleit M, et al. No efficacy of subcutaneous methotrexate in active ankylosing spondylitis: a 16-week open-label trial. Ann Rheum Dis 2007; 66:419-21.

54. Haibel H, Rudwaleit M, Braun J, Sieper J. Six months open label trial of leflunomide in active ankylosing spondylitis. Ann Rheum Dis 2005;64:124-6.

55. Goh L, Samanta A. A systematic MEDLINE analysis of therapeutic approaches in ankylosing spondylitis. Rheumatol Int 2009;29:1123-35.

56. Braun J, Baraliakos X, Listing J, Fritz C, Alten R, Burmester G, et al. Persistent clinical efficacy and safety of anti-tumour necrosis factor alpha therapy with infliximab in patients with ankylosing spondylitis over 5 years: evidence for different types of response. Ann Rheum Dis 2008;67:340-5.

57. Saougou I, Markatseli TE, Voulgari PV, Drosos AA. Maintained clinical response of infliximab treatment in ankylosing spondylitis: a 6-year long-term study. Joint Bone Spine 2010;77:325-9.

58. Davis JC Jr, van der Heijde DM, Braun J, Dougados M, Clegg DO, Kivitz AJ, et al. Efficacy and safety of up to 192 weeks of etanercept therapy in patients with ankylosing spondylitis. Ann Rheum Dis 2008;67:346-52.
59. Martín-Mola E, Sieper J, Leirisalo-Repo M, Dijkmans BA, Vlahos B, Pedersen R, et al. Sustained efficacy and safety, including patient-reported outcomes, with etanercept treatment over 5 years in patients with ankylosing spondylitis. Clin Exp Rheumatol 2010;28:238-45.

60. van der Heijde D, Kivitz A, Schiff MH, Sieper J, Dijkmans BA, Braun J, et al. Efficacy and safety of adalimumab in patients with ankylosing spondylitis: results of a multicenter, randomized, double-blind, placebocontrolled trial. Arthritis Rheum 2006;54:2136-46.

61. van der Heijde DM, Revicki DA, Gooch KL, Wong RL, Kupper H, Harnam N, et al. Physical function, disease activity, and health-related quality-of-life outcomes after 3 years of adalimumab treatment in patients with ankylosing spondylitis. Arthritis Res Ther 2009;11:R124.

62. van der Heijde D, Sieper J, Maksymowych WP, Dougados M, Burgos-Vargas R, Landewé R, et al. 2010 Update of the international ASAS recommendations for the use of anti-TNF agents in patients with axial spondyloarthritis. Ann Rheum Dis 2011;70:905-8.

63. Barra L, Pope JE, Payne M. Real-world anti-tumor necrosis factor treatment in rheumatoid arthritis, psoriatic arthritis, and ankylosing spondylitis: cost-effectiveness based on number needed to treat to improve health assessment questionnaire. J Rheumatol 2009;36:1421-8.

64. Furst DE, Keystone EC, Braun J, Breedveld FC, Burmester GR, De Benedetti F, et al. Updated consensus statement on biological agents for the treatment of rheumatic diseases, 2010. Ann Rheum Dis 2011;70 Suppl 1:i2-36.

65. Geusens P, Vosse D, van der Linden S. Osteoporosis and vertebral fractures in ankylosing spondylitis. Curr Opin Rheumatol 2007;19:335-9.

66. Bradley WG Jr. Low back pain. AJNR Am J Neuroradiol 2007;28:990-2. 